\title{
SARS-CoV-2: basic concepts, origin and treatment advances
}

\author{
Gerardo Santos-López, * Paulina Cortés-Hernández, Verónica Vallejo-Ruiz and Julio Reyes-Leyva
}

Instituto Mexicano del Seguro Social, Centro de Investigación Biomédica de Oriente, Puebla, Mexico

\begin{abstract}
The first cases of COVID-19, caused by the virus called SARS-CoV-2, were recorded in Wuhan, China, in December 2019; however, its transmission ability caused for the infection to be practically present throughout the world six months later. The origin of the virus appears to be zoonotic; it has been proposed that it comes from a bat and that it may have had an intermediate host that led to its introduction in the human population. SARS-CoV-2 is an enveloped virus, with a positive single-stranded RNA genome, and it binds to the angiotensin-converting enzyme, present in susceptible cells, to infect the human respiratory system. Although other coronaviruses have been previously known, they have not had the same impact, and, therefore, research on pharmacological treatments is not sufficiently developed to face the current challenge. Almost since the beginning of the epidemic, several molecules have been proposed for the treatment of infection; however, there is not yet a drug available with sufficient effectiveness for treatment. This review describes SARSCoV-2 main characteristics, its replicative cycle, its possible origin and some advances in the development of antiviral treatments.
\end{abstract}

KEY WORDS: COVID-19. Coronavirus. SARS-CoV-2. Emerging viruses. Pneumonia. Zoonosis.

\section{SARS-CoV-2: generalidades, origen y avances en el tratamiento}

\section{Resumen}

Los primeros casos de COVID-19, causada por el virus denominado SARS-CoV-2, se registraron en Wuhan, China, en diciembre de 2019; sin embargo, su capacidad de transmisión ocasionó que seis meses después la infección prácticamente estuviera presente en todo el mundo. El origen del virus parece ser zoonótico; se propone que proviene del murciélago y podría haber tenido un hospedero intermediario que llevó a su introducción en la población humana. SARS-CoV-2 es un virus envuelto, con genoma de ARN de cadena sencilla en sentido positivo y se ancla a la enzima convertidora de angiotensina, presente en las células susceptibles para infectar el sistema respiratorio de los humanos. Aunque previamente se han conocido otros coronavirus, no han tenido el mismo impacto, por lo que la investigación en tratamientos farmacológicos no tiene el desarrollo suficiente para afrontar el reto actual. Casi desde el comienzo de la epidemia se han propuesto moléculas para el tratamiento de la infección, sin embargo, aún no se cuenta con un fármaco con suficiente efectividad terapéutica. En esta revisión se describen las características principales de SARS-CoV-2, su ciclo replicativo, su posible origen y algunos avances en el desarrollo de tratamientos antivirales.

PALABRAS CLAVE: COVID-19. Coronavirus. SARS-CoV-2. Virus Emergentes. Neumonía. Zoonosis. 


\section{Appearance of a new virus}

Towards the end of 2019, a new virus emerged in Wuhan, China. Its report to the World Health Organization was reflected in a health alert to warn the international community. ${ }^{1}$ According to genetic studies, this new virus belongs to the Coronaviridae family, which includes the viruses that cause severe acute respiratory syndrome (SARS-CoV) and Middle East respiratory syndrome (MERS-CoV). Both these viruses cause severe respiratory infection in humans and have brought about epidemics that have affected different countries. ${ }^{2,3}$ The new virus was initially known as "new coronavirus 2019" and 2019 novel coronavirus (2019-nCoV). The International Committee on Taxonomy of Viruses named this new virus severe acute respiratory syndrome coronavirus 2 or SARS-CoV-2. ${ }^{4}$ Infection by this virus was officially named coronavirus disease 2019 (COVID-19). ${ }^{5}$

\section{SARS-CoV-2 characteristics}

Coronaviruses are infectious agents that are common in animals and humans. In humans, coronaviruses can cause conditions that range from common colds (HCoV-NL63, HCoV-229E, Beta-CoV1, and HCoV-HKU1), to the aforementioned serious diseases (SARS and MERS). ${ }^{6}$ Coronaviruses have an unsegmented single-stranded, positive-sense RNA genome of approximately 30 thousand nucleotides. By electron microscopy, its general shape is observed to be rounded with spicules arranged in a superficial structure that resembles a solar corona (Fig. 1), where its name derives from. ${ }^{7}$

The viral genome contains a cap structure $5^{\prime}$ end and a poly-A tail at 3'end, which is why it functions as messenger RNA. This RNA is translated to generate non-structural proteins (nsps) that have functions in the replication and maturation of proteins. However, genomic RNA gives rise to other messenger RNAs, called subgenomic, which will generate other viral proteins. This series of messengers have the 3 ' end in common, which is why they are said to be "nested", and which is where the name of the order coronaviruses belong to comes from: Nidovirales. ${ }^{8}$

Viral genome contains at least 13 open reading frames; however, processing of some polypeptides can originate multiple mature proteins. The virus has four structural proteins: the spike protein (S), the envelope protein $(E)$, the membrane protein $(M)$ and the nucleoprotein $(\mathrm{N})$, whereas non-structural proteins are at least 16 and are known as nsp1 to nsp16. ${ }^{9}$

Structural proteins form the viral particle; protein S is the most antigenic and external, in addition to providing, to a large extent, the crown shape to the virion. In the case of SARS-CoV-2, it is the protein that recognizes cellular protein ACE2 (angiotensin-converting enzyme 2) as receptor to bind to the host cell. $\mathrm{N}$ protein provides protection to the genome and is involved in viral RNA synthesis, while M provides structure and stability to the virion; $E$ is an ion channel with functions during virions assembly and exit from the host cell. ${ }^{7,10}$ Structural proteins coding regions include other open reading frames (ORFs) that encode a series of proteins called accessory and that are named ORF3a, ORF6, ORF7a, ORF7b, ORF8, ORF 9b and possibly one more called ORF14. ${ }^{9}$ These proteins are considered not to be essential for coronaviruses replication cycle; however, they have different functions when they interact with host proteins at different signaling pathways related to antiviral response. Elimination of any of these reading frames can lead to murine hepatitis coronavirus attenuation; these proteins have also been proposed to contribute to SARS-CoV pathogenesis, in addition to representing an advantage for viruses adaptation to their host. ${ }^{11}$ On the other hand, the 16 non-structural proteins include helicase, triphosphatase, methyltransferase and nuclease. Especially noteworthy is nsp5, the main of two proteases the virus has, known as Mpro (main protease) or $3 \mathrm{CL}$ pro (3C-like protease), a protease of the chymotrypsin type that intervenes in the maturation of 12 proteins, since it acts on 11 cleavage sites among viral genome translation products. ${ }^{7,9}$

\section{Coronaviruses replication cycle}

SARS-CoV-2 virion binds to the host cell by interaction of $S$ protein with its receptor, ACE2 protein, which is abundant in respiratory tissue, from the upper portion, such as that of the nasal and oral cavity, down to the lower portion, mainly in pulmonary alveoli. ${ }^{3}$

A host protein, transmembrane serine protease 2 (TMPRSS2), has been found to also play a role in the entry of the virus into cells, since it activates $S$ protein. ${ }^{12}$ The virus enters the cell by endocytosis. After interaction with the receptor, there is a conformational change in S protein, which promotes the fusion of viral and endosomal membranes in a process that requires environmental acidity. Following the release of the nucleocapsid into the cytoplasm, viral genomic RNA 


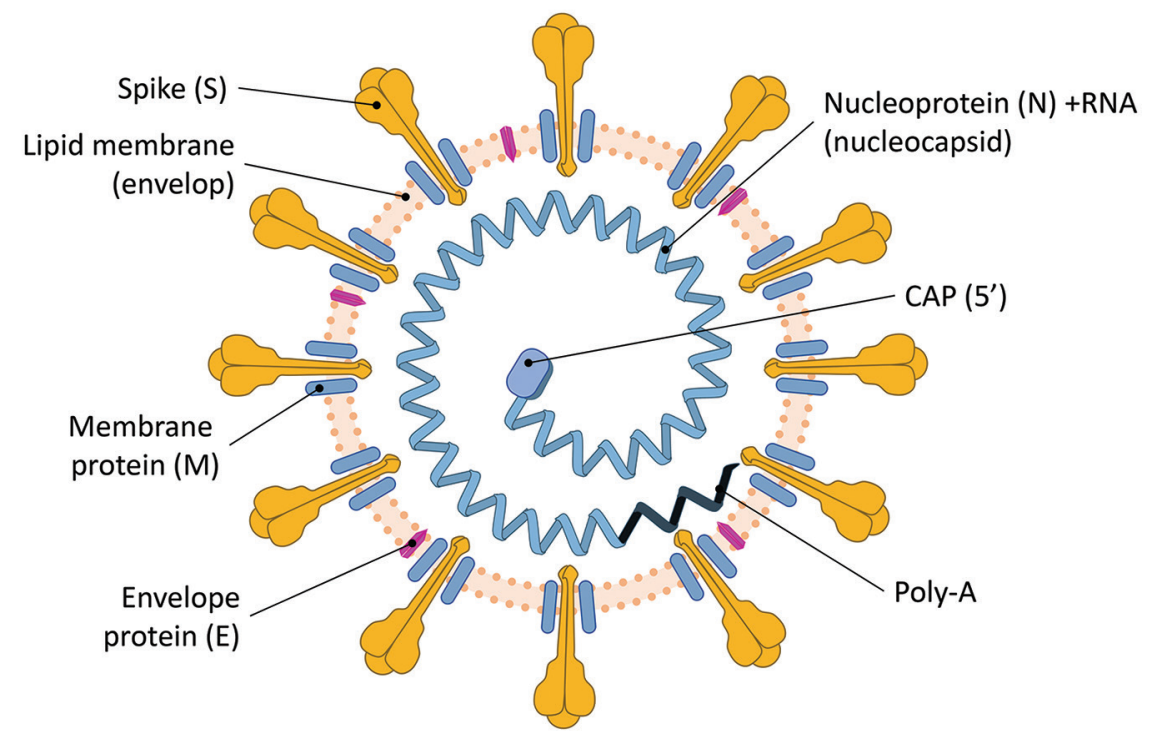

Figure 1. Simplified diagram of the SARS-CoV-2 virion. Created with information from Fehr et al. ${ }^{7}$ and Cui et al. ${ }^{27}$

is directly translated in the ribosome and the pp1a polyprotein is produced. By a reading frame shift (ribosomal frameshift) at the end of pp1a protein code, the reading frame is lengthened to generate the pp1ab polyprotein. These polyproteins are digested by viral proteases PLpro and 3CLpro to generate 16 non-structural proteins with different enzymatic functions and that are involved in viral RNA synthesis and proteolytic processing, among other activities. Some of these proteins form a complex that is responsible for the synthesis of the viral genome and the subgenomic RNA segments that will give rise to the structural proteins that are synthesized in ribosomes associated with the endoplasmic reticulum. Subsequently, viral products assemble in the intermediate compartment of the endoplasmic reticulum and the Golgi apparatus, where genomes interact with the nucleoprotein to form the nucleocapsid and with the other structural components. Finally, the viral particle forms as a vesicle on the plasma membrane, after which the new virions leave the cell by exocytosis. ${ }^{10}$ The main steps in this process are shown in figure 2.

\section{Probable drugs for COVID-19 treatment}

Research on pharmacological treatments for COVID-19 is highly relevant. So far, no drug has been approved for specific treatment. However, various studies show that there are molecules with probable specific activity against some constituents of the virus or that can reduce the inflammatory process in patients. During the first weeks of the epidemic in China, treatment with several drugs successfully tested for other viruses was reported, for example, interferon alpha (antiviral cytokine), ribavirin (guanosine analog) and the combination of lopinavir and ritonavir (retroviral protease inhibitors):;1-15 however, no conclusive results have been obtained that allow establishing that these drugs are useful for the treatment of COVID-19.

Some other drugs have been tested in in vitro assays and are capable, to varying degrees, of inhibiting SARS-CoV infection, including nelfinavir, glycyrrhizin, and baicalein, ${ }^{16}$ and it has therefore been proposed that they may have activity against SARS-CoV-2. Other drugs that appear to be good options are antibodies that block interleukin 6 receptor (e.g., sarilumab and tocilizumab), which can attenuate the pro-inflammatory cytokine secretion that is characteristic of patients with severe COVID-19. These antibodies are used for the treatment of some inflammatory diseases such as rheumatoid arthritis. ${ }^{17,18}$ Other molecules that have proven their activity in vitro are nafamostat mesylate, an anticoagulant that inhibits the TMPRSS2 enzyme, which is important for the entry of the virus into the cell, ${ }^{19}$ and the lipopeptide EK1C4, which, by interacting with viral $S$ protein is capable of inhibiting the fusion of viral and host membranes, which prevents the virus from depositing its genetic material in the cytoplasm. ${ }^{20}$ Favipiravir has also been proposed, which is a pyrazine analog whose effect has been shown to inhibit the polymerase of influenza viruses and other viruses; 


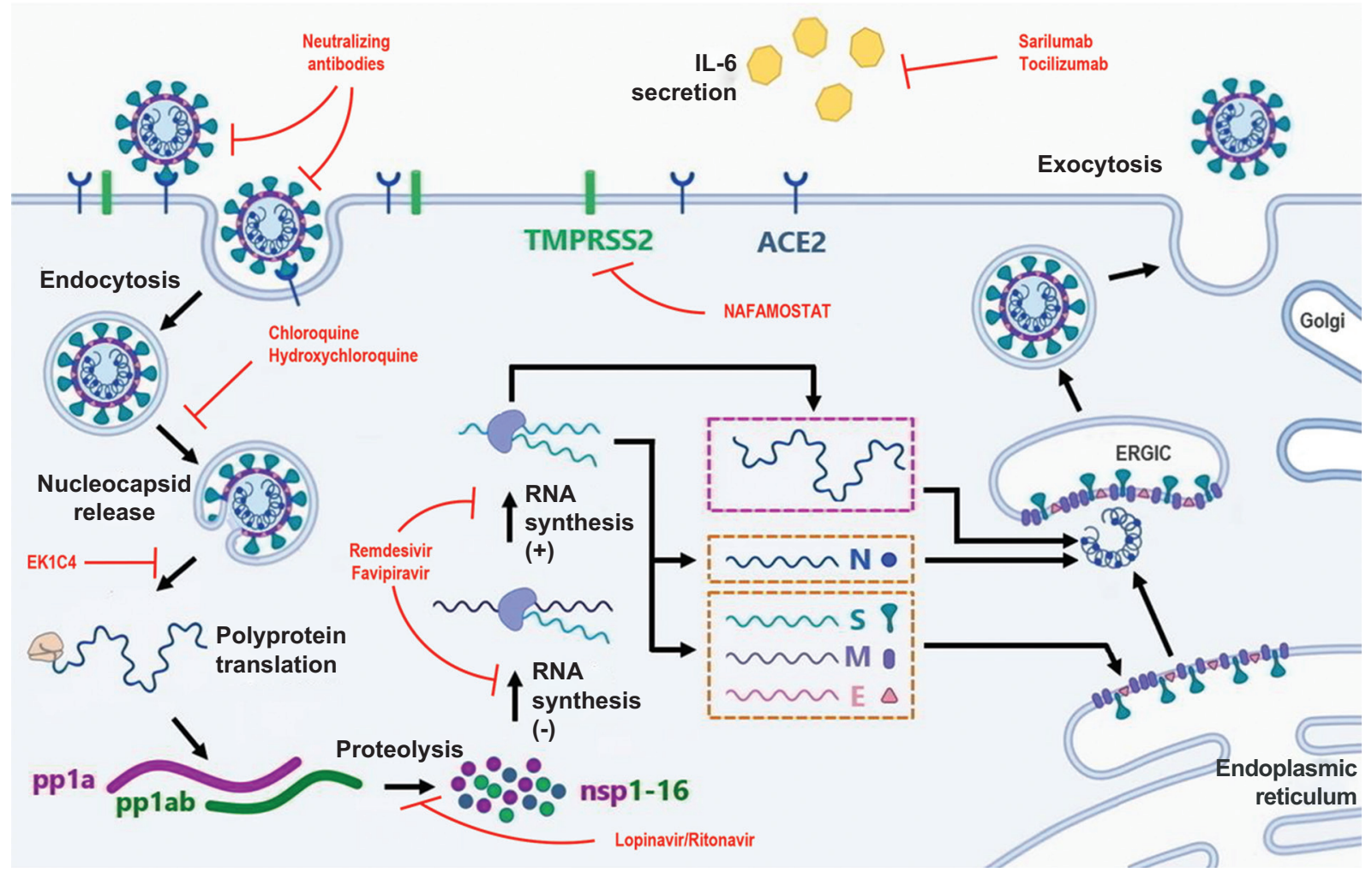

Figure 2. Representation of coronaviruses replication cycle. Texts in red color indicate the points where the probable drugs act to inhibit or reduce SARS-CoV-2 infection. Created in part with BioRender.com, with information from Fehr et al. ${ }^{7}$ and Lim et al. (2020).

however, a recent article reported that it had little effect on SARS-CoV-2 infection in an experimental hamster model. ${ }^{21}$ Some of these drugs are indicated at their site of action in figure 2.

There are few clinical studies with these drugs that show any effect of improvement in patients. In a clinical trial with 1,063 patients, 538 received remdesivir, and 521, placebo; those in the remdesivir group recovered on average four days earlier, and although a decrease in mortality was also observed, it was not statistically significant with regard to the control group. ${ }^{22}$ On the other hand, in a clinical trial with tocilizumab that included 21 severely ill patients in China, symptoms, hypoxemia, and opacity on CT images improved with the treatment in most patients. ${ }^{23}$ In midJune, the RECOVERY clinical trial reported that dexamethasone, a steroidal anti-inflammatory drug commonly used in patients with severe respiratory disease, decreased mortality in patients hospitalized for severe COVID-19. When two thousand treated patients were compared against four thousand controls, dexamethasone prevented one out of every eight deaths in patients on mechanical ventilation and one out of every 25 deaths in patients who required oxygen; it had no effect on moderate infection that did not require oxygen. ${ }^{24}$

Another explored resource is the use of convalescent plasma. In a clinical trial carried out in China with 103 patients, 52 were treated with plasma from convalescent individuals and 51 constituted the control group; $52 \%$ of the patients who received plasma experienced clinical improvement, and only $43 \%$ of the control group did, although the differences were not statistically significant. The same occurred with mortality, in which there was a tendency to be lower in the convalescent plasma group..$^{25}$ Despite these advances, there is insufficient evidence to claim that an effective pharmacological treatment for patients with COVID-19 exists.

\section{SARS-CoV-2 origin}

As it has been documented in other coronaviruses that infect human beings, SARS-CoV-2 zoonotic origin was proposed since the beginning, essentially owing to its close phylogenetic proximity to a coronavirus previously found in a bat, with the genome of which it has more than $96 \%$ identity. ${ }^{3}$ Previously, two coronaviruses responsible for mild respiratory infection circulated in 
humans: 229E and OC43. SARS virus, which causes severe pneumonia, was discovered in 2003. Between 2004 and 2005, other two coronaviruses, called NL63 and HKU1, were detected in humans; both generally cause mild infections. Phylogenetic studies have provided evidence that NL63 and 229E originated in bats, while OC43 and HKU1 come from rodents. ${ }^{26}$ To enter the human population, these viruses had an intermediate host with extensive contact with humans, which in the case of 229E it was alpaca and in OC43, cattle. Regarding the NL63 and HKU1 viruses, the intermediate host is still unknown, while in SARS-CoV and MERS-CoV there is evidence that intermediate hosts were the civet and the dromedary, respectively. ${ }^{26-28}$

Based on phylogenetic studies, SARS-CoV-2 has been proposed to originate from the Bat-CoV RaTG13 bat virus, since it is the most similar, with $96 \%$ of identity. So far, the species that could have acted as an intermediary for SARS-CoV-2 to jump from bats to humans has not been defined. One of the main differences between SARS-CoV-2 and Bat-CoV RaTG13 is found in $S$ protein receptor-binding domain; however, this small sequence is very similar to that found in Malayan pangolin (Manis javanica) coronaviruses, although overall identity between pangolin coronaviruses genomes and those of SARS-CoV-2 is approximately $90 \%$. The presence in SARS-CoV-2 of that small sequence that is similar in the pangolin coronavirus suggests that there were recombination events between a pangolin and a bat virus, and that pangolin could have acted as intermediary for the bat coronavirus to reach the human being. However, SARS-CoV-2 has another sequence in the same $S$ protein, rich in basic amino acids, susceptible to digestion by proteases and important for the replication cycle that is not present in bat or pangolin coronaviruses. ${ }^{29-31}$ Therefore, the hypothesis of the pangolin as intermediate host is still under discussion. Pangolin illegal trade is common in China, particularly for the use of its scales in traditional medicine, as well as for its meat, considered of high nutritional value, ${ }^{32}$ hence the fact that it is not difficult for human contact with these wild animals to be involved in SARS-CoV-2 emergence.

\section{Final comments}

It is difficult for the emergence of a new or unknown virus to be predicted. In the $21^{\text {st }}$ century, there have been some epidemics of greater or lesser impact caused by different viruses we do not usually coexist with, among which we can mention the influenza $A$
H1N1 (2009), Zika, chikungunya, Ebola, SARS and MERS viruses. However, if a review about viruses with pandemic potential is made, the list grows significantly. The question is if despite not knowing which virus or viruses may emerge as threats to global health, nations can be better prepared to deal with them.

With these essentially zoonotic health crises, identification of viruses in wildlife animals became fundamental. In fact, a variety of viruses with probabilities to cause outbreaks in humans and with relative potential to cause pandemics have since been reported. However, it is still a scientific activity that for many is just a matter of curiosity, without considering the relevance it can have on public health and global well-being, which is essentially reflected in the lack of resources for scientific and technological research. ${ }^{33}$

Most emerging viruses are caused by zoonosis, which is due, among other factors, to the fact that humans increasingly invade unexplored areas where there are wild species they rarely had contact with before. Some of these animals are captured for commercial purposes, e.g., for use as food, as part of traditional medicine remedies or as pets. Invasion of these species' habitat leads to contact with their microbiota and to the generation of health emergencies from time to time. ${ }^{34}$ For this reason, the aforementioned activities, already regulated in many countries, should be strongly monitored and, where appropriate, sanctioned.

The COVID-19 pandemic will not be the last health emergency faced by humanity. Little by little we have detected the areas where we have to be prepared, and governments and supranational entities must assume the responsibility for coordinating this effort to avoid the damages that are currently being experienced by SARS-CoV-2 emergence.

\section{Conflict of interests}

The authors declare that they have no conflicts of interest.

\section{Funding}

The authors did not receive any sponsoring to carry out this article.

\section{Ethical disclosures}

Protection of human and animal subjects. The authors declare that no experiments were performed on humans or animals for this research. 
Confidentiality of data. The authors declare that no patient data appear in this article.

Right to privacy and informed consent. The authors declare that no patient data appear in this article.

\section{References}

1. World Health Organization [Internet]. Pneumonia of unknown origin China; 2020.

2. Zhu N, Zhang D, Wang W, Li X, Yang B, Song J, et al. A novel coronavirus from patients with pneumonia in China, 2019. N Engl J Med. 2020;382:727-733.

3. Zhou P, Yang XL, Wang XG, Hu B, Zhang L, Zhang W, et al. A pneumonia outbreak associated with a new coronavirus of probable bat origin. Nature. 2020;579:270-273.

4. Coronaviridae Study Group of the International Committee on Taxonomy of Viruses. The species severe acute respiratory syndrome-related coronavirus: classifying 2019-nCoV and naming it SARS-CoV-2. Nat Microbiol. 2020;5:536-544.

5. World Health Organization [Internet]. Naming the coronavirus disease (COVID-19) and the virus that causes it; 2020.

6. Song Z, Xu Y, Bao L, Zhang L, Yu P, Qu Y, et al. From SARS to MERS, thrusting coronaviruses into the spotlight. Viruses. 2019;11:59.

7. Fehr AR, Perlman S. Coronaviruses: an overview of their replication and pathogenesis. Coronaviruses. 2015;1282:1-23.

8. Lau SK, Chan JF. Coronaviruses: emerging and re-emerging pathogens in humans and animals. Virol J. 2015;12:209.

9. SARS coronavirus 2 (SARS-CoV-2) proteome. ViralZone [Internet]; 2020.

10. Lim YX, Ng YL, Tam JP, Liu DX. Human coronaviruses: a review of virus-host interactions. Diseases. 2016;4:26.

11. Liu DX, Fung TS, Chong KK, Shukla A, Hilgenfeld R. Accessory proteins of SARS-CoV and other coronaviruses. Antiviral Res. 2014;109:97-109.

12. Hoffmann M, Kleine-Weber H, Schroeder S, Kruger N, Herrler T, Erichsen S, et al. SARS-CoV-2 cell entry depends on ACE2 and TMPRSS2 and is blocked by a clinically proven protease inhibitor. Cell. 2020;181:271-280.

13. Yan Y, Shin WI, Pang YX, Meng Y, Lai J, You C, et al. The first 75 days of novel coronavirus (SARS-CoV-2) outbreak: recent advances, prevention, and treatment. Int J Environ Res Public Health. 2020;17:2323.

14. Huang $C$, Wang $Y$, Li X, Ren L, Zhao J, Hu Y, et al. Clinical features of patients infected with 2019 novel coronavirus in Wuhan, China. Lancet. 2020;395:497-506.

15. Zhou F, Yu T, Du R, Fan G, Liu Y, Liu Z, et al. Clinical course and risk factors for mortality of adult inpatients with COVID-19 in Wuhan, China: a retrospective cohort study. Lancet. 2020;395:1054-1062.

16. Cheng VC, Lau SK, Woo PC, Yuen KY. Severe acute respiratory syndrome coronavirus as an agent of emerging and reemerging infection. Clin Microbiol Rev. 2007;20:660-694.
17. Guo C, Li B, Ma H, Wang X, Cai P, Yu Q, et al. Tocilizumab treatment in severe COVID-19 patients attenuates the inflammatory storm incited by monocyte centric immune interactions revealed by single-cell analysis. bioRxiv. 2020:029769.

18. Regeneron and Sanofi Begin Global Kevzara® (sarilumab) Clinical Trial Program in Patients with Severe COVID-19 [Internet]. Regeneron; c2020.

19. Yamamoto M, Kiso M, Sakai-Tagawa $Y$, Iwatsuki-Horimoto K, Imai M, Takeda $M$, et al. The anticoagulant nafamostat potently inhibits SARSCoV-2 S protein-mediated fusion in a cell fusion assay system and viral infection in vitro in a cell-type-dependent manner. Viruses. 2020;12:629.

20. Xia S, Liu M, Wang C, Xu W, Lan Q, Feng S, et al. Inhibition of SARSCoV-2 (previously 2019-nCoV) infection by a highly potent pan-coronavirus fusion inhibitor targeting its spike protein that harbors a high capacity to mediate membrane fusion. Cell Res. 2020;30:343-355.

21. Kaptein SJ, Jacobs S, Langendries L, Seldeslachts L, ter Horst S, Liesenborghs L, et al. Antiviral treatment of SARS-CoV-2-infected hamsters reveals a weak effect of favipiravir and a complete lack of effect for hydroxychloroquine. bioRxiv. 2020:159053.

22. Beigel JH, Tomashek KM, Dodd LE, Mehta AK, Zingman BS, Kalil AC et al. Remdesivir for the treatment of Covid-19 - preliminary report. $\mathrm{N}$ Engl J Med. 2020;383:993-994.

23. Xu X, Han M, Li T, Sun W, Wang D, Fu B et al. Effective treatment of severe COVID-19 patients with tocilizumab.Proc Natl Acad Sci U S A. 2020;117:10970-10975.

24. Low-cost dexamethasone reduces death by up to one third in hospitalised patients with severe respiratory complications of COVID-19. Recovery [Internet]; 2020.

25. Li L, Zhang W, Hu Y, Tong X, Zheng S, Yang J, et al. Effect of convalescent plasma therapy on time to clinical improvement in patients with severe and life-threatening COVID-19: a randomized clinical trial. JAMA. 2020;324:1-11.

26. Forni D, Cagliani R, Clerici M, Sironi M. Molecular evolution of human coronavirus genomes. Trends Microbiol. 2017;25:35-48.

27. Cui J, Li F, Shi ZL. Origin and evolution of pathogenic coronaviruses. Nat Rev Microbiol. 2019;17:181-192.

28. Ye ZW, Yuan S, Yuen KS, Fung SY, Chan CP, Jin DY. Zoonotic origins of human coronaviruses. Int J Biol Sci. 2020;16:1686-1697.

29. Liu P, Jiang JZ, Wan XF, Hua Y, Li L, Zhou J, et al. Are pangolins the intermediate host of the 2019 novel coronavirus (SARS-CoV-2)? PLoS Pathog. 2020;16:e1008421.

30. Andersen KG, Rambaut A, Lipkin WI, Holmes EC, Garry RF. The proximal origin of SARS-CoV-2. Nat Med 2020;26:450-452.

31. Han GZ. Pangolins harbor SARS-CoV-2-related coronaviruses. Trends Microbiol. 2020;28:515-517.

32. Wanli Y. Concerns mount for chinese pangolin. China: China Daily [Internet]; 2020.

33. Morse SS, Mazet JA, Woolhouse M, Parrish CR, Carroll D, Karesh WB, et al. Prediction and prevention of the next pandemic zoonosis. Lancet. 2012;380:1956-1965.

34. Santos-López G, Vallejo-Ruiz V. El factor humano en el surgimiento y resurgimiento de infecciones virales. Invest Clin. 2010;51:1-3. 